\title{
Optimization production conditions of photosynthetic purple bacteria biomass at pilot scale to remove sulphide from aquaculture pond
}

Tối ưu hóa các điều kiện để sản xuất sinh khối vi khuẩn tía quang hợp ở quy mô pilot tạo chế phẩm xủ lý sulphide trong đáy ao nuôi trồng thủy sản.

Research article

Do Thi Lien ${ }^{*}$, Do Thi To Uyen ${ }^{1}$, Le Thi Nhi Cong", Hoang Phuong Ha', ${ }^{1,2}$ Cung Thi Ngoc $\mathrm{Mai}^{1}$

${ }^{1}$ Institute of Biotechnology, Vietnam Academy of Science and Technology, 18 Hoang Quoc Viet, Cau Giay, Ha Noi, Vietnam; ${ }^{2}$ Graduate University of Science and Technology, Vietnam Academy of Science and Technology, 18 Hoang Quoc Viet, Cau Giay, Ha Noi, Vietnam

\begin{abstract}
For the purpose of sulphide removal in aquaculture ponds, three strains (name: TH21, QN71, QN51) were isolated and selected with the highest sulphide removal activity from Thanh Hoa and Quang Ninh coastal zones. These strains have identified and tested in a number of aquaculture ponds in different areas with good water quality results. With the objective of purple non sulfur bacteria biomass production containing 3 selected strains for wide application and suitable price for farmers, in this study, we study on optimum conditions of mixed purple non sulfur bacteria biomass production at pilot scale. The results showed that the sources of substrates were soybean meal $(1 \mathrm{~g} / \mathrm{l})$ and acetate $(0.5 \mathrm{~g} / \mathrm{l})$. These substrates are low cost, easy to find, convenient in large culture. The mixture of photosynthetic bacteria can be cultured in glass tanks, under micro aerobic and natural lighting conditions that produce highly concentrated photosynthetic bacteria and lowest rest media.
\end{abstract}

\begin{abstract}
Nhằm mục tiêu xủ lý sulphide trong môi truờng nuôi trồng thủy sản, chúng tôi đã phân lập và lụa chọn được ba chủng vi khuẩn tía quang hợp có khả năng loại bỏ sulphide cao nhất ký hiệu TH21, QN71, QN52 tù̀ các vùng ven biển Thanh Hóa và Quảng Ninh. Các chủng này đã đuợc định loại và thư nghiệm tại một số ao nuôi thủy sản ở các vùng khác nhau thu được kết quả tốt về chất lượng nước. Để tạo chế phẩm vi khuẩn tía quang hợp tù 3 chủng lựa chọn được ưng dụng rộng rãi và có giá thành phù hợp cho nông hộ, trong nghiên cưu này, chúng tôi nghiên cứu tối ưu hóa các điều kiện sản xuất sinh khối hỗn hợp 3 chủng vi khuẩn tía quang hợp ở quy mô pilot. Kết quả cho thấy đã tìm kiếm được nguồn co chất là bột đậu tuơng $(1 \mathrm{~g} / \mathrm{l})$ và acetate $(0.5 \mathrm{~g} / \mathrm{l})$ là nhũng chất có giá thành thấp, dễ tìm kiếm, thuận tiện trong nhân nuồi ở quy mô lớn. Hốn hợp vi khuẩn tía quang hợp có thể nuôi trong các bể kính, ở điều kiện vi hiếu khí, có ánh sáng chiếu tụ nhiên có thể sản xuất được chế phẩm vi khuẩn tía quang hợp có mật độ cao, cơ chất còn lại sau sản xuất là it nhất.
\end{abstract}

Keywords: $\quad$ purple non sulfur bacteria, Rhodovulum sulfidophillum; Rhodobacter sphaeroides; sulphide

\section{Introduction}

Sulphide is generated from the rest feed and animal waste, which accumulates at the bottom of the aquaculture ponds and is converted an aerobically by microbes (Kutako et al., 2009). The toxicity of sulphide is mainly due to the inhibition of cytochrome $\mathrm{C}$ oxidase and to interference with other crucial enzymes, mainly by $\mathrm{H}_{2} \mathrm{~S}$ (Affonso et al., 2002; Konishi et al., 2013). The presence of sulphide also can provide a favourable condition for bacterial proliferation and increase the rate of bacterial infection in sediment-dwelling animals (Bourgeois and Felder, 2001). The studies of sulphide on aquatic animals indicate that 
sulphide is highly toxic at concentrations frequently found in natural and polluted environments, as well as in shrimp and crab ponds, and especially in ponds densely stocked with animals (Ritvoet al.,2007). Due to the benthic habit of most crab and shrimp species, a few studies have reported the toxic effect of sulphide or the response of some species to sulphide exposure from the aspect of the immune response. Susceptibility to common pathogens is increased in the Asian paddle crab Charybdis japonica (Cheng et al., 2007; Palazzo et al., 2014) and the kuruma shrimp Marsupenaeus japonicas (Chenget al., 2007; Hagerman and Vismann, 1995; Konishi et al., 2013). This means that they should be controlled at levels that are safe for shrimp and fish growth. Among the microbes associated with the carbon, nitrogen and sulphur cycles, of aquaculture ponds, purple non-sulphur bacteria (PNSB) are probably the most useful to improve the water quality during shrimp and fish cultivation (Antony and Philip, 2006 and Zhou et al., 2009). PNSB are versatile organisms able to grow with photoautotrophic or photoheterotrophic or heterotrophic conditions depending on the availability of light, oxygen and a suitable source of carbon. This means that they can consume organic matter under light and dark conditions and some can also remove $\mathrm{H}_{2} \mathrm{~S}$ (Antony and Philip, 2006 and Kornochalert et al., 2014). Normally, PNSB exist in illuminated anoxic habitats in nature such as in aquatic sediments, of freshwater rivers and lakes, and wastewater treatment systems including shrimp ponds (Panwichian et al., 2010). PNSB are also considered to be beneficial microbes as their cells have a high protein content, they produce essential amino acids, and contain a high content of vitamin B12, ubiquinone and carotenoids (Shapawi et al., 2012 and Kornochalert et al., 2014), so they have a great potential for use as probiotics in aquaculture (Shapawi et al., 2012).

In Viet Nam, aquaculture is fast growing and profitable, but farmers are facing epidemics and environmental pollution. At present, in the Vietnamese market, there are many biological products to remove sulphide from bottom of aquaculture pond. Several kinds of them are imported with high cost, and some products commonly used as Pro$\mathrm{w}$, Sanolife... are not functional removal of sulphide. Therefore, it is necessary to produce bioproductof purple non sulfur bacteria from a screening process for useful native bacteria that not only maintain microbiological and environmental protection but also reduce the cost to meet real needs. In previous reports, we have presented the results of the selection and biological characteristics of the three strains with highest sulphide removal activity (Do Thi Lien., 2008; 2009).

The aims of this study were to optimize conditions for production of photosynthetic purple bacteria biomass at pilot scale for sulphide removal in aquaculture ponds.

\section{Materials and methods}

\subsection{Materials}

The study was carried out by using mixture of purple non sulphur bacteria strains including Rhodobacter sphaeroides $\mathrm{QN}_{71}, \quad$ Rhodobacter sphaeroides $\mathrm{QN}_{52}$ and
Rhodovulum sulfidophillum $\mathrm{TH}_{21}$ with high sulphide removal capacity. Three strains were isolated from the bottom of aquaculture ponds from Thanh Hoa and Quang Ninh coastal. A number of biological characteristics were investigated at Environmental Biotechnology LaboratoryInstitute of Biotechnology, Vietnam Academy of Science and Technology.

DSMZ 27 medium which consists of the following components: (1L); $\mathrm{K}_{2} \mathrm{HPO}_{4}: 1 \mathrm{~g} ; \mathrm{KH}_{2} \mathrm{PO}_{4}: 0,5 \mathrm{~g} ; \mathrm{MgSO}_{4}$. $7 \mathrm{H}_{2} \mathrm{O}: 0.4 \mathrm{~g} ; \mathrm{NaCl}: 15 \mathrm{~g} ; \mathrm{NH}_{4} \mathrm{Cl}: 0.4 \mathrm{~g} ; \mathrm{CaCl}_{2} .2 \mathrm{H}_{2} \mathrm{O}$ : $0.05 \mathrm{~g}$; yeast extract: $0.3 \mathrm{~g}$; sodium acetate: $1 \mathrm{~g}$; succinic acid: $0.5 \mathrm{~g}$; trace element solution: $1 \mathrm{ml}$; vitamin solution: $1 \mathrm{ml}$; agar: $20 \mathrm{~g}$; filled distilled water to $1000 \mathrm{ml}$; $\mathrm{pH}$ of the medium: $6.8-7.0$ before autoclaving. The trace element solution (1L): $\mathrm{HCl}(25 \%) 6,5 \mathrm{ml} ; \mathrm{FeCl}_{2} .4 \mathrm{H}_{2} \mathrm{O} 1,5 \mathrm{~g}$; $\mathrm{H}_{3} \mathrm{BO}_{3} 0,3 \mathrm{~g} ; \mathrm{MnCl}_{2} \cdot 2 \mathrm{H}_{2} \mathrm{O} 0,03 \mathrm{~g} ; \mathrm{CoCl}_{2} \cdot 6 \mathrm{H}_{2} \mathrm{O} 0.2 \mathrm{~g}$; $\mathrm{ZnSO}_{4}$. $7 \mathrm{H}_{2} \mathrm{O} 0,1 \mathrm{~g} ; \mathrm{CuCl}_{2} \cdot 2 \mathrm{H}_{2} \mathrm{O} 17 \mathrm{mg} ; \mathrm{NiCl}_{2} \cdot 6 \mathrm{H}_{2} \mathrm{O} 24$ $\mathrm{mg} ; \mathrm{Na}_{2} \mathrm{MoO}_{4} \cdot 2 \mathrm{H}_{2} \mathrm{O}: 36 \mathrm{mg}, \mathrm{H}_{2} \mathrm{O} 993 \mathrm{ml}: 1 \mathrm{ml}$. The vitamin solution (1L) contain thiamine, $500 \mu \mathrm{g}$; niacin, $500 \mu \mathrm{g}$ and biotin, $15 \mu \mathrm{g}$ in $1000 \mathrm{ml}$ of distilled water is disinfected with a filter and added to the medium before use.

\subsection{Methods}

\section{Culturing mixture of three purple non sulfur bacteria}

In the laboratory: mixture of purple non sulfur bacteria are cultured in glass flask or cylindrical glass jars with a rubber cap. The medium in the glass flasks is aerated with sterilized nitrogen gas replacing oxygen in the medium then dissolved oxygen concentration is $0 \mathrm{mg} / \mathrm{l}$. Mixture of purple non sulphur bacteria are cultured under anaerobic conditions, and their growth in the logarithmic phase with a cell density of about $10^{9}$ transferred to a test flask with a volume of about $5-10 \%(\mathrm{v} / \mathrm{v})$ to reach an initial density at OD800 of 0.1 . The light intensity at the surface of the tests were controlled by incandescent lamps

Pilot scale: mixed purple non sulphur bacteria are cultured in plastic tanks or glass tanks with volume of 100 litter containing soybean and acetate media, placed outdoors in natural light.

\section{Growth of purple photosynthetic bacteria assessment}

Evaluating the growth capacity of the bacteria by determining the optical density increase of the cell suspension at the $800 \mathrm{~nm}$ wavelength $\left(\mathrm{OD}_{800}\right)$ on the spectrophotometer.

Determination of COD content: Mixture of purple non sulphur bacteria were centrifuged at $9000 \mathrm{r} / \mathrm{min}$ for 10 min. The supernatant was used to analysis COD by APHA standard methods [3].

Statistical analysis: All experiments in this study were conducted in three replicates. Mean values and the standard deviations are presented. Analysis of the data using one-way ANOVA and significant differences at a p-value $<0.05$. 


\section{Results and discussion}

\subsection{Selection of some suitable substrate sources of culturing media}

Although the mixture of three purple non sulfur bacterial strains were well grown in the DSMZ 27 media, it is aimed to select the appropriate substrates which are easy to use and cost effective for biomass production at pilot scale. We have determined the biomass accumulation capacity of the mixed purple non sulfur bacterial strains in DSMZ 27 media, carbon sources in media were replaced by some kinds of substrates such as acetate, succinate, glucose, glutamate, rice flour or soybean powder with amount of $1 \mathrm{~g} / \mathrm{l}$. The experiment was conducted under anaerobic conditions. The results determining the biomass accumulation of the mixture purple non sulfur bacterial strains for 5 days were estimated by $\Delta \mathrm{OD} 800$ and are presented in Figure 1 and Figure 2.

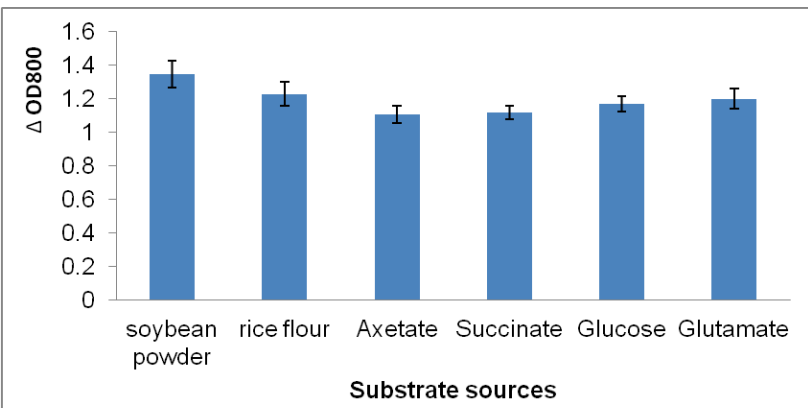

Figure 1. Levels of biomass accumulation in different media

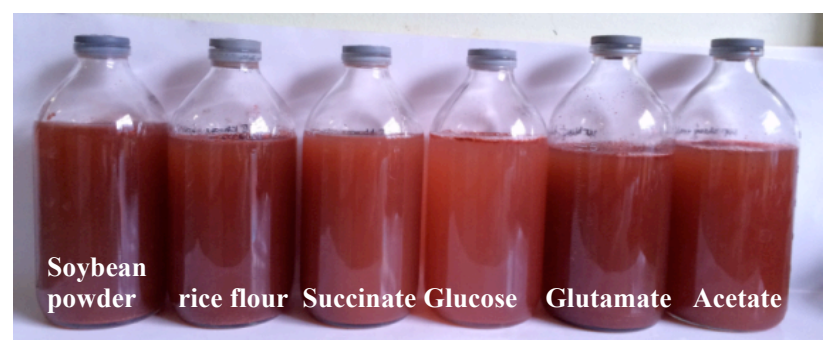

Figure 2. Mixture cultured in different substrate sources

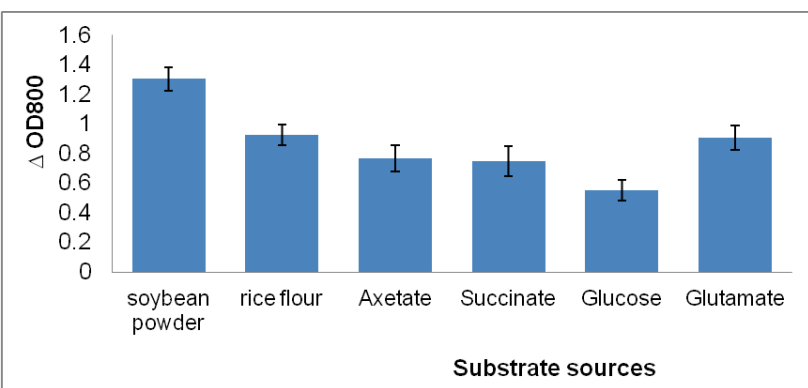

Figure 3. Levels of biomass accumulation in media containing only substrate sources

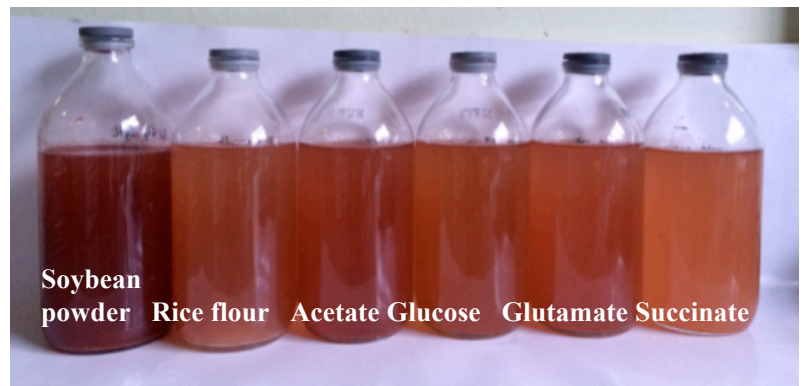

Figure 4. Mixture cultured in media containing only substrate sources

The results showed that the mixture grow well on media containing substrates such as acetate, succinate, glucose, glutamate, rice flour and soybean powder. In particular, the growth of strains is the best on the medium containing the substrate of soybean powder. However, the DSMZ 27 media were replaced carbon by soybean powder, which include many expensive chemicals such as yeast, trace element and contain many components. It is not convenient to produce biomass at pilot scale. Therefore, we continue to test with media that contain only substrate sources of acetate, succinate, glucose, glutamate, rice flour and soybean powder with $1 \mathrm{~g} / \mathrm{l}$. The experiment was preceded under anaerobic conditions. The results of determining the biomass accumulation (in accordance with $\Delta$ OD800) of the mixed strains of purple non sulfur bacteria for 5 days are presented in Figure 3 and 4.

The results indicated that the mixture of purple non sulphur bacterial strains grew best on media containing only soybean powder with significant difference from each other media containing acetate, succinate, glucose, glutamate or rice flour $(\mathrm{p} \leq 0.05)$. Hence, soybean powder was used for further experiment.

\subsection{Selection of the optimal soybean powder concentrations for biomass production}

Bioproduct of purple non sulphur bacteria will be added directly to the aquaculture ponds periodically to treat sulphide, so bioproduct of purple non sulphur bacteria with the rest nutrient will pollute the secondary environment. Thus, study to find the exact composition of media which is just enough for the high-density growth of purple non sulphur bacteria and no nutrient redundancy is necessary.

In this experiment, mixture of three purple bacterial strains are cultured in media containing soybean powder at concentrations from $0.2 \mathrm{~g} / \mathrm{l}$ to $2 \mathrm{~g} / \mathrm{l}$. Results of their biomass accumulation (by $\Delta$ OD800) after 5 culture days are shown in Figure 5 and 6. 


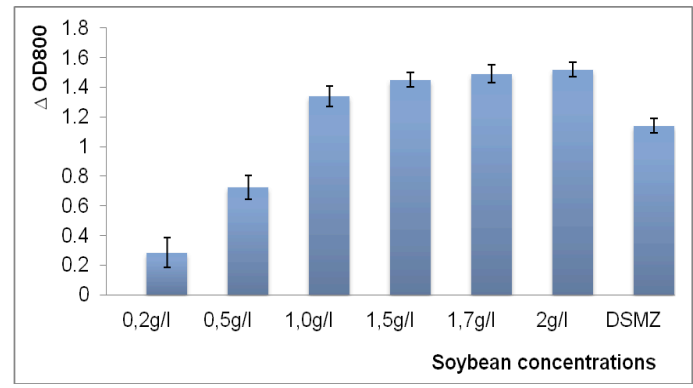

Figure 5. Levels of biomass accumulation in different soybean concentrations

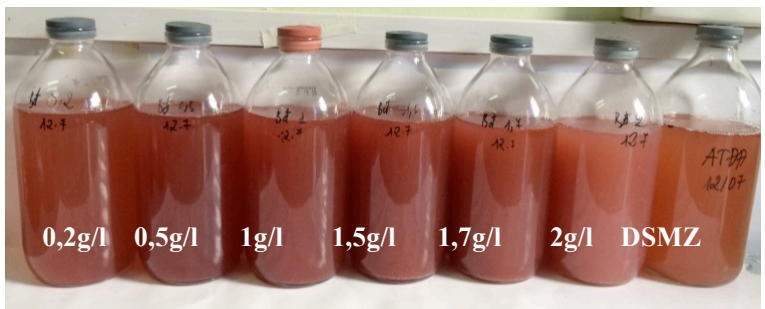

Figure 6. The mixed were cultured on different concentrations of soybean media

The results indicated that the density of mixed purple non sulphur bacteria was increased along with increasing of soybean concentration. The higher concentration, the greater density of mixed purple non sulphur bacteria in the medium. There was a gradual increase in biomass from the $0.2 \mathrm{~g} / \mathrm{L}$ concentration to the $2 \mathrm{~g} / 1$ concentration. At a substrate concentration of less than $1 \mathrm{~g} / 1(0.2$ and 0.5 $\mathrm{g} / \mathrm{l})$, the growth of strains of purple non sulphur bacteria is poorly, ranging from 28.5 to $72.6 \%$. Collected biomass in media containing soybean concentrations from 1 to $2 \mathrm{~g} / \mathrm{l}$ is higher than in the DSMZ 27 media. The difference in biomass accumulation at concentrations of 1 with $1.5,1.7$ and $2 \mathrm{~g} / \mathrm{l}$ is no statistically significant difference ( $\mathrm{p} \geq 0.05)$. We conducted an assessment of excess nutrient concentrations in the culture medium (by COD) at soybean concentrations from $1-2 \mathrm{~g} / \mathrm{l}$. Result are shown in Table 1.

\section{Table 1. Remaining COD concentration in culture} media

\begin{tabular}{cc} 
Soybean concentrations $(\mathrm{g} / \mathrm{l})$ & COD $\left(\mathbf{O}_{\mathbf{2 m g}} / \mathbf{l}\right)$ \\
\hline 1 & 92 \\
1,5 & 247 \\
1,7 & 535 \\
2 & 864
\end{tabular}

The results showed that the highest biomass production was achieved in medium containing $2 \mathrm{~g} / \mathrm{l}$ of soybean powder, but the COD content in the medium was the highest. So, the medium containing soybean concentrations of $1 \mathrm{~g} / 1$ was selected and supplemented other sources of substrates.

\subsection{Study on combining soybean powder with other carbon sources}

The objective of this part is to improve the substrate quality and expand the production of purple non sulfur bacteria without leaving the high rate of COD. Acetate and glutamate were carbon sources which are low cost, easy to find and quite good for purple non sulfur bacteria growth (Fig 4), Culturing medium contains soybean (1 g/l) supplemented with another carbon sources such as acetate or glutamate (concentrations from $0.5-1 \mathrm{~g} / 1$ ). After five days of standing culture in illumination, the results were presented on the Table 2 .

Table 2. Growth and remaining COD in the culture media

\begin{tabular}{lccc}
\multicolumn{2}{c}{ Media } & $\mathbf{\Delta O D}(\mathbf{8 0 0})$ & $\mathbf{C O D}\left(\mathbf{O}_{\mathbf{2 m g}} / \mathbf{l}\right)$ \\
\hline $\begin{array}{l}\text { Soybean }(1 \\
\text { g/l) add 0,5 }\end{array}$ & Acetate & $\mathbf{1 , 5 1 5} \pm \mathbf{0 . 0 5}$ & 74 \\
g/l carbon & Glutamate & $1,332 \pm 0.02$ & 101 \\
$\begin{array}{l}\text { sources } \\
\text { Soybean (1 }\end{array}$ & Acetate & $\mathbf{1 , 5 3 0} \pm \mathbf{0 . 0 5}$ & 97 \\
g/l) add 1 & & & \\
g/l carbon & Glutamate & $1,432 \pm 0.04$ & 117 \\
Sources & & & \\
Soybean $(2 \mathrm{~g} / \mathrm{l})$ & & $1,52 \pm 0.04$ & 857 \\
DSMZ -27 & $1,205 \pm 0.02$ & 104
\end{tabular}

The results in Table 2 showed that the highest biomass accumulation was in the medium containing soybean powder $(1 \mathrm{~g} / \mathrm{l})$ supplemented with acetate carbon (at 0.5 and $1 \mathrm{~g} / 1$ concentrations). The biomass accumulation in these media and soybean medium containing $2 \mathrm{~g} / 1$ soybean meal were not statistically significant different $(\mathrm{p} \geq 0.05)$. The COD concentration in the medium contain ing soybean $(1 \mathrm{~g} / 1)$ and acetate $(0.5 \mathrm{~g} / \mathrm{l})$ was the lowest. Thus, it is possible to use medium containing soybean $(1 \mathrm{~g} / \mathrm{l})$ and acetate $(0.5 \mathrm{~g} / \mathrm{l})$ to produce purple nonsulfur bacteria biomass at pilot scale for high biomass accumulation and the lowest rest media.

\subsection{Study on the effect of culture conditions on purple bacteria biomass production}

Purple non sulfur bacteria grow optimally on anaerobic conditions with illuminate, but for pilot biomass production, anaerobic conditions such as in the laboratory are difficult. So, we conducted the culture in media containing soybean meal $(1 \mathrm{~g} / \mathrm{l})$ and acetate $(0.5 \mathrm{~g} / 1)$ in three conditions: anaerobic (nitrogen aeration, rubber cap, oxygen concentration 0mg / 1); micro aerobic condition (static flask, oxygen concentration from $0.5-1 \mathrm{mg} / \mathrm{l}$ ) and aerobic (shake $120 \mathrm{rpm}$, oxygen concentration $>6 \mathrm{mg} / \mathrm{l}$ ) under light. Results of their biomass accumulation (by $\Delta$ OD800) after 5 culture days are shown in Figure 7.
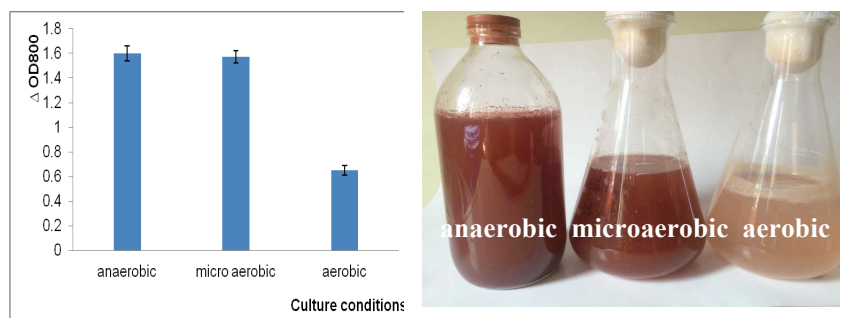

Figure 7. The ability of biomass accumulation in culture conditions

The results showed that the biomass accumulation of the mixed purple bacteria at micro aerobic and anaerobic conditions is similar and there is no statistically significant difference $(p \geq 0.05)$. Under aerobic conditions, the 
growth of the mixed was lowest, there was statistically significant difference compared with anaerobic and micro aerobic conditions. Thus, mixed purple non sulfur bacteria are not only the ability to grow in anaerobic conditions - light, but also in micro aerobic conditions- light. Therefore, the production of biomass in large tanks does not require absolute anaerobic.

\subsection{Study the growth of purple photosynthet- ic bacteria on different material containers to produce biomass at pilot scale}

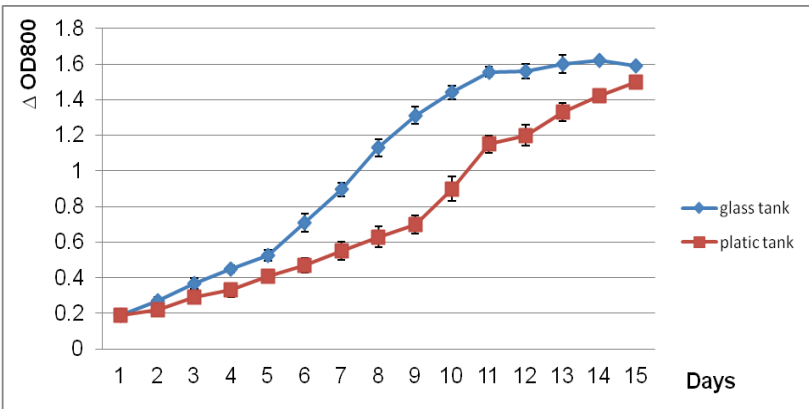

Figure 8. PNSB culture in different material bioreactors

After finding the appropriate substrate sources and concentrations, we conducted PNSB culture at pilot scale, such as glass tanks (100 l) and plastic tanks (100 l), under light-anaerobic condition. The aim of this experiment is finding the material that make the best condition for the biomass production of PNSB. The experiment was conducted in natural conditions, with a temperature of about $35-37^{\circ} \mathrm{C}$, biomass accumulation was monitored daily. Results were shown in Figure 8.

The results showed that the growth of PSNB in natural conditions affected by the day-night cycle and by weather, the growth of purple non sulphur bacteria was slower than conditions of light in laboratory. The growth rate in glass tank was faster than plastic tank. It takes about 10 days for high density in glass tank and 15 days in plastic tank. This explains that glass tanks can absorb more light than plastic tanks. Thus, production of biomass in scale pilot, we can use glass tanks to culture the mixed purple non sulphur bacteria to make bio-product.

\section{Conclusion}

- The medium for culturing of mixed purple non sulphur bacteria on pilot scale contains soybean powder $(1 \mathrm{~g} / 1)$ and acetate $(0.5 \mathrm{~g} / \mathrm{l})$. Medium is cost effective, high biomass accumulation and no surplus substance.

- The glass tank was selected to culture purple non sulphur bacteria to obtain high biomass at pilot scale.

Acknowledgement: This research is funded by the Institute of Biotechnology, Vietnam Academy of Science and Technology, under grant number CSKH18-02.

\section{References}

[1] Cheng SY., Hsu SW., Chen JC., (2007). Effect of sulphide on the immune responseand susceptibility to Vibrio alginolyticus in the kuruma shrimp. Marsupenaeus japonicus. Fish and Shellfish Immunology (22), 16-26.

[2] Kornochalert, Kantachote D., Chaiprapat S., Techkarnjanaruk S. (2014) Use of Rhodopseudomonas palustris P1 stimulated growth by fermented pineapple extract to treat latex rubber sheet wastewater to obtain single cell protein. Annual Microbiology, 64(3), 1021-1032

[3] The Government of the S.R. of Vietnam (2006) The Government's Decree no. 32/2006/NĐ-CP in management of endangered, precious and rare forest plants and animals.

[4] Konishi M., Watsuji TO., Nakagawa S., Hatada Y., Takai K., Toyofuku T., (2013) Effects of hydrogen sulphide on bacterial communities on the surface ofgalatheid crab, Shinkaiacrosnieri, and in a bacterial mat cultured in rearing tanks. Microbes and Environment (28), 25-32.

[5] Kutako M., Powtongsook S., Menasveta (2009) Effect of illumination in nitrogen P. conversion and microorganism diversity in sediment from shrimp pond. Phycologia 48(sp4), 154-159.

[6] Palazzo G., Colafemmina G., Iudice CG., Mallardi A., (2014). Three immobilized enzymes acting in series in layer by layer assemblies: exploiting thetrehalase-glucose oxidase-horseradish peroxidase cascade reactions for the optical determination of trehalose. Sensors and Actuators B: Chemical 202, 217-223.

[7] Shapawi R., Ting TE., -Azad Sal (2012) Inclusion of Purple Non-sulfur Bacterial Biomass in Formulated Feed to Promote Growth, Feed Conversion Ratio and Survival of Asian Seabass Lates calcarifer Juveniles. Journal of Fisheries and Aquatic Science $7(6), 475-480$.

[8] Antony P., Philip R. (2006) Bioremediation in shrimp culture systems NAGA, World Fish Center Q., 29(3-4), 62-66.

[9] Do Thi Lien, Do Thi To Uyen, Tran Van Nhi (2008). Characterization of a purple photosynthetic bacterium of the genus Rhodobacter isolated from coastal of Quang Ninh province. Journal of Biotechnology, Vietnamese Academy of Science and Technology 6(4), 497- 504.

[10] Do Thi Lien, Do Thi To Uyen, Tran Van Nhi (2009). Characterization of a purple photosynthetic bacterium of the genus Rhodovullum with capacity removed sulphide in wastewater. National Biotechnology Conference. November 26 - 27Th 2009, Thai Nguyen. 954 - 958 .

[11] Zhou Q., Li K., Jun X., Bo L. (2009) Role and functions of beneficial microorganisms in sustainable aquaculture. Bioresour. Technol. 100, 3780-3786.

[12] Panwichian S., Kantachote D, Wittayaweerasak B., 
Mallavarapu M. (2010) Isolation of purple nonsulfur bacteria for the removal of heavy metals and sodium from contaminated shrimp ponds. Electron. Biotechnol., 13(4). DOI: 10.2225/vol13-issue4-fulltext-8

[13] Affonso E., Polez V., Correa C., Mazon A., Araujo, M., Moraes G., Rantin F., (2002). Blood parameters and metabolites in the teleost fish Colossoma macropomum exposed to sulfide or hypoxia. Comp. Biochem. Physiol. C: Toxicol. Pharmacol. (133), 375-382.

[14] Bourgeois RP., Felder DL., (2001). Postexposure metabolic effects of sulphide and evidence of sul- phide-based ATP production in callianassid ghost shrimp (Crustacea:Decapoda:Thalassinidea). Exp. Mar. Biol. Ecol. 263, 105-121.

[15] Ritvo G., Dixon JB., Neill WH., SamochaTM., Lawrence AL., 2007. The effect of controlled soil sulfur concentration on growth and survival of Litopenaeus vannamei. Word. Aquacult. Soc. 31, 381-389.

[16] Hagerman L., Vismann B., (1995). Anaerobic metabolism in the shrimp Crangoncrangon exposed to hypoxia, anoxia and hydrogen sulphide. Mar. Biol. $123,235-240$. 